\title{
"Effect of marble powder with and without silica fume on mechanical properties of concrete"
}

\author{
V.M.SHELKE ${ }^{1 *}, \quad$ Prof. P.Y.PAWDE ${ }^{2} \quad$ Dr. R.R.SHRIVASTAVA ${ }^{3}$ \\ ${ }^{*} P$ G Student - M.Tech (Env. Engg) \\ ${ }^{2}$ Prof-.Civil Engg. Dept. \\ ${ }^{3}$ Prof-Chemistry Dept. \\ G. H. Raisoni College of Engineering \& Technology, NAGPUR, (India) - 440016
}

\begin{abstract}
Leaving the waste materials to the environment directly can cause environmental problem. Hence the reuse of waste material has been emphasized. Waste can be used to produce new products or can be used as admixtures so that natural resources are used more efficiently and the environment is protected from waste deposits. Marble stone industry generates both solid waste and stone slurry. Whereas solid waste results from the rejects at the mine sites or at the processing units, stone slurry is a semi liquid substance consisting of particles originating from the sawing and the polishing processes and water used to cool and lubricate the sawing and polishing machines. Stone slurry generated during processing corresponds to around $40 \%$ of the final product from stone industry. This is relevant because the stone industry presents an annual output of 68 million tones of processed products. Therefore the scientific and industrial community must commit towards more sustainable practices. There are several reuse and recycling solutions for this industrial by-product, both at an experimental phase and in practical applications. These industrial wastes are dumped in the nearby land and the natural fertility of the soil is spoiled. The physical, chemical and mechanical properties of the waste are analyzed.

In this project our main objective is to study the influence of partial replacement of cement with marble powder, and to compare it with the compressive strength of ordinary M30 concrete. We are also trying to find the percentage of marble powder \& silica fume replaced in concrete that makes the strength of the concrete maximum. Now a day's marble powder has become a pollutant. So, by partially replacing cement with marble powder, we are proposing a method that can be of great use in reducing pollution to a great extent.

In this investigation a series of compression tests were conducted on 150mm, cube and $150 \mathrm{~mm} x$ $300 \mathrm{~mm}$, cylindrical specimens using a modified test method that gave the complete compressive strength, using silica fume of constant $8 \%$ with and without marble powder of volume fractions $0,8,12, \& 16 \%$ on Ordinary Portland cement concrete.
\end{abstract}

Keywords: Ordinary Portland cement, Marble powder, Silica fume, Compressive strength.

\section{Introduction}

1.1 Influence of Marble Dust (Powder) in Concrete.

The advancement of concrete technology can reduce the consumption of natural resources and energy sources and lessen the burden of pollutants on environment. Presently large amounts of marble dust are generated in natural stone processing plants with an important impact on environment and humans. This project describes the feasibility of using the marble dust in concrete production as partial replacement of cement. In INDIA, the marble and granite stone processing is one of the most thriving industry the effects if varying marble dust contents on the physical and mechanical properties of fresh and hardened concrete have been investigated. Slump and air content of fresh concrete and absorption and compressive strength of hardened concrete were also investigated.

\subsection{Application of Silica Fume in Concrete}

The American concrete institute (ACI) defines silica fume as a "very fine noncrystalline silica produced in electric arc furnaces as a byproduct of production of elemental silicon or alloys containing silicon". Silica fume is also known as micro silica, condensed silica fume, volatized silica or silica dust. It is usually a grey colored powder, somewhat similar to Portland cement or some fly ashes. It can exhibit both pozzolanic and cementitious properties. Silica fume has been recognized as a pozzolanic admixture that is effective in enhancing the mechanical properties to a great extent. Addition of silica fume to concrete improves the durability of concrete, compressive strength of concrete, abrasion resistance, reduces permeability and also in protecting the embedded steel from corrosion. 


\subsection{Literature Review}

The effects of silica fume on compressive strengths on high strength lightweight concrete was done by H. Katkhuda, B. Hanayneh and N. Shatarat. They carried out by replacing cement with different percentages of silica fume at different constant water-binder ratio keeping other mix design variables constant. The silica fume was replaced by $0 \%$, and $8 \%$ for a water-binder ratios ranging from 0.26 to 0.42 . For all mixes, compressive strength were determined at $7 \& 28$ days. The results showed that the compressive strengths increased with silica fume incorporation but the optimum replacement percentage is not constant because it depends on the watercementitious material $(w / c)$ ratio of the mix. Based on the results, a relationship between compressive strengths of silica fume concrete was developed using statistical methods.

Quarrying of raw materials (limestone and clay) for the production of cement is becoming the source of environmental degradation. To produce one ton of Portland cement, 1.6 tons of raw materials are needed and the extraction of raw materials from the earth is $20 \%$ faster than the earth replenish it, so raw materials consumed in 12 months will take 14.4 months to be filled back [5].

Many researchers from the world are working on this serious issue created by cement and one of the solutions is the introduction of polymeric cement by the development of inorganic alumina-silicate polymer [4]. A binder can be obtained by the reaction of industrial by-products such as fly-ash (FA) [6], [7], silica fume (SF) [8] with the alkaline liquid.

In 1979, Joseph Davidovits created and applied the term geopolymer because polymerization process takes place, in which $\mathrm{Si}$ and $\mathrm{Al}$ present in the source material (FA/SF), reacts with the alkaline liquid to produce binders.

Portland cement [4] that will ultimately lead to the decrease in global warming and depletion of ozone layer.

\subsection{Ordinary Portland Cement}

\section{Materials Used}

IS: $8112-1989$ for 43 Grade. The properties of cement tested were Fineness $(90 \mu$ Sieve $)=8 \%$, Normal consistency $=27.5 \%$, Initial \& Final setting time $=185$ minute $\& 275$ minute and 28 days Compressive strength $=55.5 \mathrm{Mpa}$.

\subsection{Silica Fume}

Silica fume having fineness by residue on 45 micron sieve $=0.7 \%$, specific gravity $=2.27$, Moisture Content $=0.72 \%$ were used. The chemical analysis of silica fume (Grade 920-D): silicon dioxide $=86.7 \%$, LOI at 975 [degrees] C $=1.7 \%$ and carbon $=0.92 \%$, are conforming to ASTM C1240-1999 standards.

\subsection{Fine Aggregate}

Locally available river sand passing through $4.75 \mathrm{~mm}$ IS sieve, conforming to grading zone-II of IS: 383-1970 was used. The physical Properties of sand like Fineness Modulus, Specific Gravity, water absorption, Bulk Density, \& Moisture Content were 2.473, 2.60, and $1.5 \%, 2492 \mathrm{Kg} / \mathrm{m}^{3} \& 0.8 \%$.

\subsection{Course Aggregate}

Crushed natural rock stone aggregate of maximum nominal size up to $20 \mathrm{~mm}$ (A1) and aggregate passing $10 \mathrm{~mm}$ (A2) were used. The combined specific gravity, Bulk Density and water absorption of $20 \mathrm{~mm} \& 10 \mathrm{~mm}$ were $2.91,2492 \mathrm{~kg} / \mathrm{m} 3,1.0 \% \& 1.5 \%$ @ 24hrs.Fineness modulus of 20mm \& 10mm aggregate were 2.810 .

\subsection{Marble Powder}

Marble Powder collected in marble shops at Gangabai ghat Rd Area, Nagpur. It was used in project. It conforms IS: 4031-1988 (Part-11) and has a specific gravity of 2.813

\subsection{Super Plasticizer.}

Sulphonated Naphthalene formaldehydecondensate CAC-35U. Super plasticizer was used. It conforms to IS: 9103-1999 [16] and has a specific gravity of 1.22 .

\subsection{Water.}

Water conforming to as per IS: 456-2000[19] was used for mixing as well as curing of Concrete specimens.

\section{Experimental Set-up}

Experimental investigation is carried out to study the properties of M30 grade of concrete. Silica Fume of $8 \%$ with addition of marble powder with various percentage as $0 \%, 8 \%, 12 \% \& 16 \%$ by the volume of concrete. The mix proportion was (1:2.03:2.7) of cement $400 \mathrm{Kg} / \mathrm{m}^{3}$ with W/C Ratio 0.43 and ratio of course aggregate A1:A2 was 70:30. The 150 X 150 X $150 \mathrm{~mm}$ cubes and 150 X $300 \mathrm{~mm}$ Cylinder were casted. The compressive strength was carried out at the age of 7 and 28 days, at various $\%$ of marble powder and $8 \%$ of silica fume. 


\subsection{Workability}

\section{Test Results and Discussions}

The workability of silica fume with and without marble powder has found to decrease than normal concrete. It appeared that the addition of super plasticizer improves the workability. Super plasticizer was added range of $0.25 \%$ to $1.05 \%$ by weight of cementations materials for maintaining the slump up to $35 \mathrm{~mm}$.

\subsection{Compressive Strength $\left(\mathbf{f}_{\mathrm{c}}\right)$ \\ (Cube \& Cylinder)}

1) Effect of Marble Powder.

a) Compressive strength of marble powder (Cube \& Cylinder) for $8 \%, 12 \% \& 16 \%$ replacement with OPC cement at 7 and 28 days is marginally decreased. Showed Table 1 . \& Figure $1 \& 4$.

\section{Effect of Silica Fume.}

a) Compressive strength of Silica Fume (Cube \& Cylinder) for 8\% replacement with OPC cement at 7 and 28 days is increased by $3.65 \%, 8.58 \%$ \& $7.30 \%, 6.05 \%$. Showed Table 1. \& Figure $2 \& 5$.

\section{Combined Effect of Silica Fume}

\section{\& Marble Powder.}

a) Compressive strength of $8 \%$ silica fume with $8 \%$ marble powder (Cube \& Cylinder) replacement with OPC cement at 7 and 28 days is increased by $1.64 \%, 3.92 \% \& 2.79 \%, 1.78 \%$. And,

b) Compressive strength of $8 \%$ silica fume with $12 \%$ marble powder (Cube \& Cylinder) replacement with OPC cement at 7 and 28 days is decreased by $6.35 \%, 5.06 \% \& 10.30 \% \& 20.76 \%$. And,

c) Compressive strength of $8 \%$ silica fume with $16 \%$ marble powder (Cube \& Cylinder) replacement with OPC cement at 7 and 28 days is decreased by $12.18 \%, 14.79 \%$ \& $20.83 \% \& 31.95 \%$. Showed Table1. \& Figure 3 \& 6 .

Table 1:- Experimental results of compressive strength of cube $\&$ cylinder at 7 days $\& 28$ days of age.

\begin{tabular}{|c|c|c|c|c|c|c|c|}
\hline $\begin{array}{l}\mathbf{S} . \\
\mathbf{N}\end{array}$ & $\begin{array}{l}\text { Age of } \\
\text { Curing }\end{array}$ & $\begin{array}{l}\text { Marbl } \\
\text { e } \\
\text { Powde } \\
\mathbf{r}\end{array}$ & $\begin{array}{l}\text { Silica } \\
\text { Fume }\end{array}$ & $\begin{array}{l}\text { Comp. } \\
\text { Strength } \\
\text { of Cube } \\
(\mathrm{Mpa})\end{array}$ & $\begin{array}{l}\text { Increasing } \\
\text { strength of }(\%) \\
\text { error }\end{array}$ & $\begin{array}{l}\text { Comp. strength } \\
\text { of Cylinder } \\
\text { (Мpa) }\end{array}$ & $\begin{array}{l}\text { Increasing } \\
\text { strength of } \\
(\%) \text { error }\end{array}$ \\
\hline 1 & \multirow{5}{*}{7} & 0 & 0 & 34.81 & 0.00 & 30.43 & 0.00 \\
\hline 2 & & 0 & 8 & 36.08 & 3.65 & 32.65 & 7.30 \\
\hline 3 & & 8 & 8 & 35.38 & 1.64 & 31.28 & 2.79 \\
\hline 4 & & 12 & 8 & 32.60 & -6.35 & 28.89 & -5.06 \\
\hline 5 & & 16 & 8 & 30.57 & -12.18 & 25.93 & -14.79 \\
\hline 6 & \multirow{5}{*}{28} & 0 & 0 & 45.13 & 0.00 & 44.32 & 0.00 \\
\hline 7 & & 0 & 8 & 49.0 & 8.58 & 47.00 & 6.05 \\
\hline 8 & & 8 & 8 & 46.90 & 3.92 & 45.11 & 1.78 \\
\hline 9 & & 12 & 8 & 40.48 & -10.30 & 35.12 & -20.76 \\
\hline 10 & & 16 & 8 & 35.73 & -20.83 & 30.16 & -31.95 \\
\hline
\end{tabular}

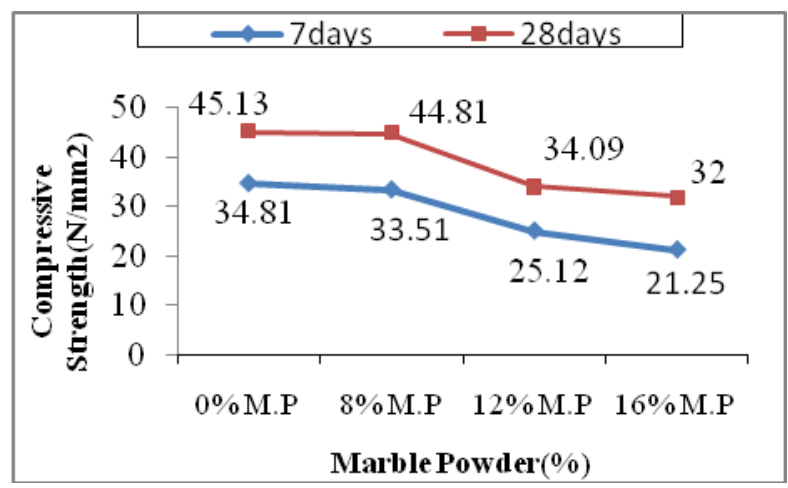

Figure 1: Compressive strength (Cubes) at 7, 28 days for 0\%, 8\%, 12\%, and 16\% of Marble Powder. 


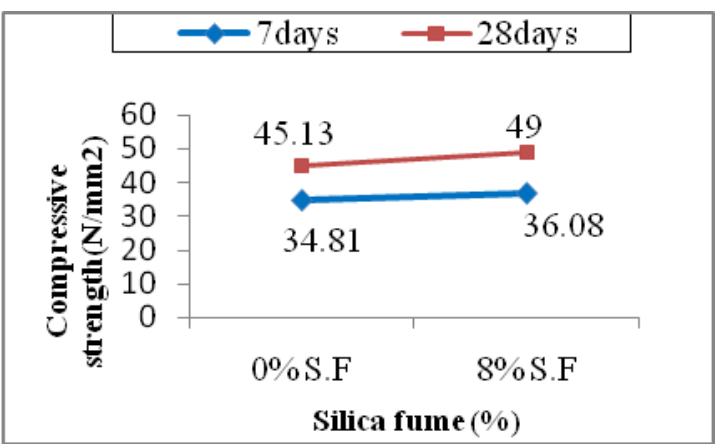

Figure 2: Compressive strength (Cube) at 7, 28 days for 0\% and 8\% of Silica Fume.

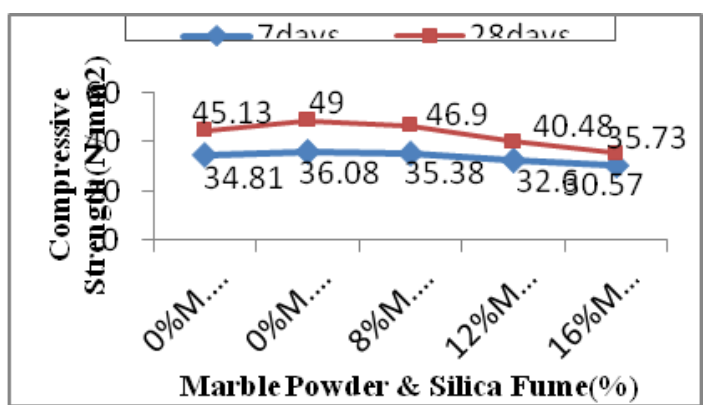

Figure 3: Compressive strength (Cube) at 7, 28 days for $8 \%$ Silica Fume with $0 \%, 8 \%, 12 \%, \& 16 \%$ Marble Powder.

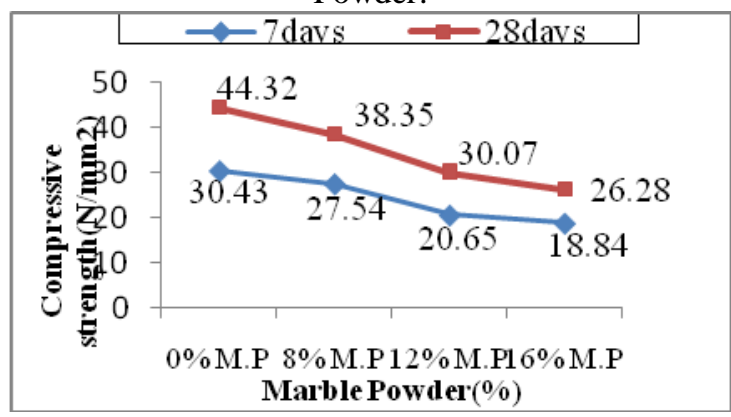

Figure 4: Compressive strength (Cylinder) at 7, 28 days for 0\%, 8\%, 12\%, and 16\% of Marble Powder.

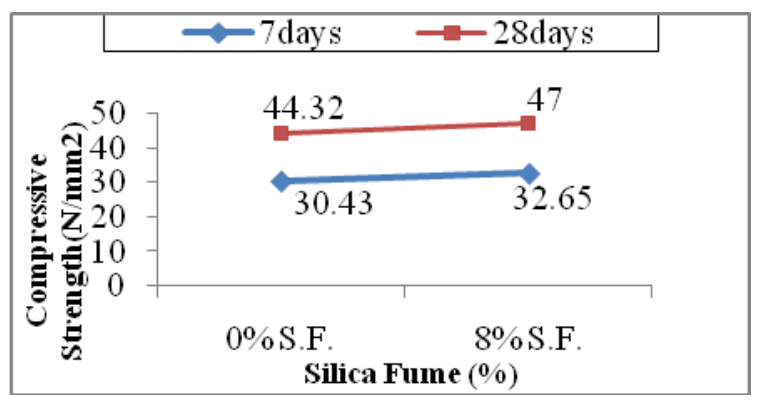

Figure 5: Compressive strength (Cylinder) at 7, 28 days for $0 \%$ and $8 \%$ of Silica Fume. 


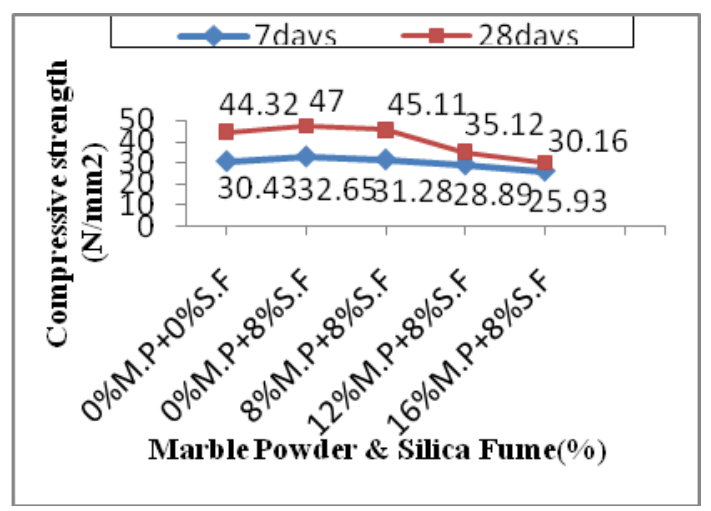

Figure 6: Compressive strength (Cylinder) at 7, 28 days for $8 \%$ Silica Fume with 0\%, 8\%, 12\%, \& 16\% Marble
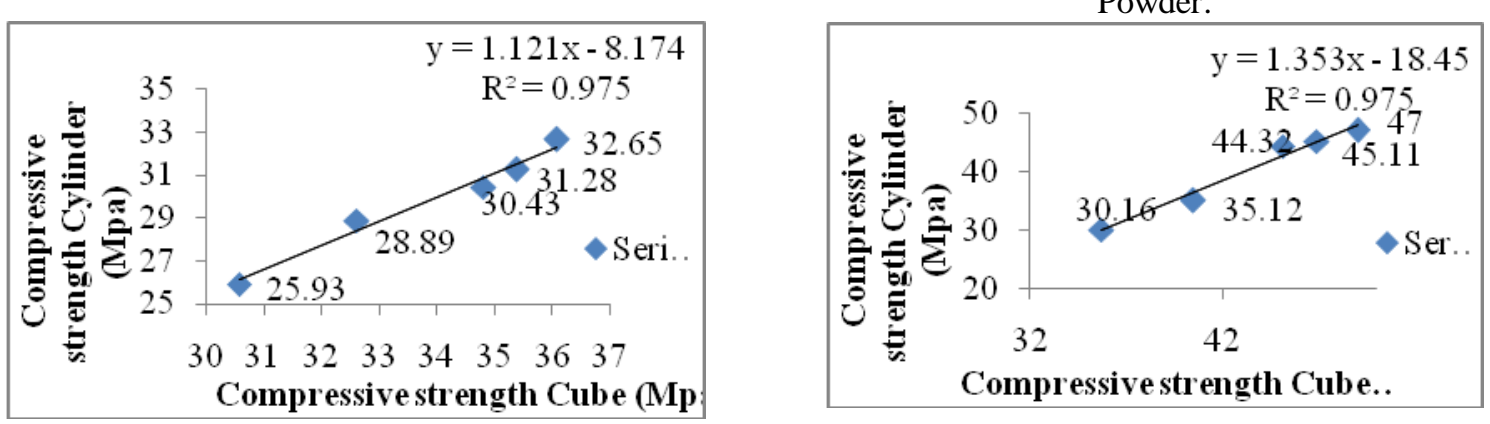

Figure 7: Relationship between Compressive strength of Cube \& Compressive strength of Cylinder at 7days of $8 \%$ Silica Fume \& 0\%, 8\%, 12\%, \& 16\% Marble Powder.

Figure 8: Relationship between Compressive strength of Cube \& Compressive strength of Cylinder at 28 days of $8 \%$ Silica Fume \& $0 \%, 8 \%, 12 \%, \& 16 \%$ Marble Powder Compressive strength of Cube and cylinder at 28 days of $8 \%$ Silica Fume \& 0\%, 8\%, 12\%, \& 16\% Marble Powder Cube and Compressive strength of cylinder at 7 days of $8 \%$ Silica Fume

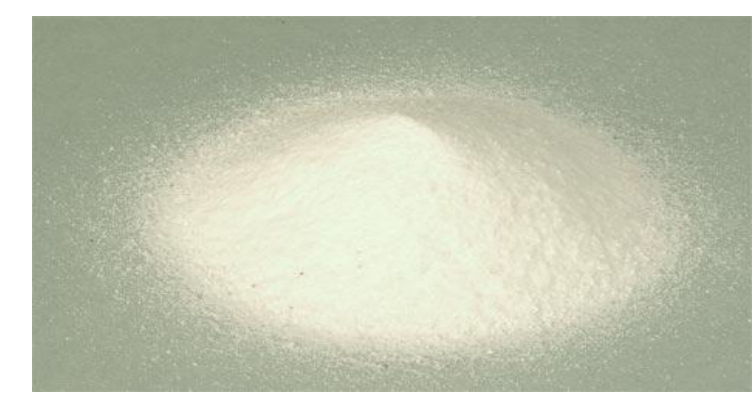

Figure 13: Showed Marble Powder.

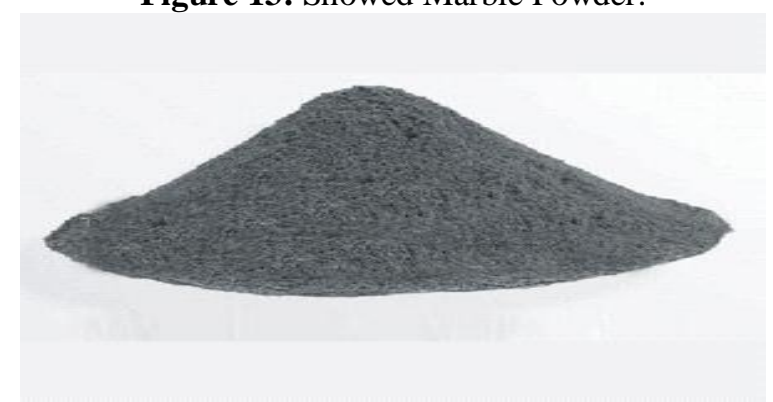

Figure 14: Showed Silica Fume

\section{Conclusions}

Following conclusions were obtained base on the experimental investigations. 
1. The workability of concrete is decreases, with addition of silica fume \& silica fume with marble powder by the replacement of cement.

2. The compressive strength of cube \& cylinder is marginally decreases, by using $8 \%, 12 \% \& 16 \%$ replacement of OPC cement with marble powder in concrete.

3. The compressive strength of cube is increased up to $3.65 \%, 8.58 \%$ at 7 days \& 28 days of curing by using $8 \%$ replacement of OPC cement with silica fume.

4. The compressive strength of cylinder is increased up to $7.30 \%, 6.05 \%$ at 7 days \& 28 days of curing by using $8 \%$ replacement of OPC cement with silica fume.

5. The compressive strength of cube $\&$ cylinder is marginally decreases by using $12 \%$ marble powder \& $8 \%$ silica fume at $7 \& 28$ days of curing as shown in figure $3 . \&$ table 1 .

6. For other combination, the compressive strength of cube \& cylinder is marginally decreases by using $16 \%$ marble powder \& $8 \%$ silica fume at $7 \& 28$ days of curing as shown in figure $3 . \&$ table 1 .

7. The optimum result of compressive strength of cube is found at $8 \%$ silica fume and $8 \%$ marble powder with replacement of OPC cement in concrete that is $1.64 \%, 3.92 \%$ at $7 \& 28$ days of curing.

8. The optimum result of compressive strength of cylinder is found at $8 \%$ silica fume and $8 \%$ marble powder with replacement of OPC cement in concrete that is $2.79 \%, 1.78 \%$, at $7 \& 28$ days of curing.

\section{Acknowledgement}

The authors would like to express their sincere appreciation for providing marble powder by Kohinur,Taj, Newraj Marble shops At Gangabai Ghat Rd Area, Nagpur and Super plasticizer by Black cat Enterprises (p) Ltd. Nagpur.

References
[1] Alengaram U.J, Mahmud H , Jumaat M.Z. "Development of lightweight concrete using industrial waste material, palm kernel shell as lightweight aggregate and its properties." Chemical, Biological and Environmental Engineering (ICBEE), 2010 2nd International Conference on Dated: 2-4 Nov. 2010

Dept. of Civil Eng., Univ. of Malaya, Kuala Lumpur, Malaysia Page (s): 277-281 Product Type: Conference Publications.

[2] Er. Harpal Aujla, Er. Raj M. Khan, Er. Vikrant Ramasesh Iyer, Er. Kaushal Kishore ,Vincent T. H. CHU “Project on Partial Replacement of Cement with Marble Powder."

[3] Alexander, S.; Greber, B. 1991. Environmental ramifications of various materials used in construction and manufacture in the United States.. Gen. Tech. Rep. PNW-GTR-277. Portland, OR: U.S. Department of Agriculture, Forest Service, Pacific Northwest Research Station. 21 p.

[4] J.Davidovits, “Geopolymer properties and chemistry,”in1 st European Conference on Soft Minerallurgy,Geopolymer'88 Compiegne France 1998, pp. 25-48.

[5] Tarun.R.Naik. WU, Z., "Development of high performance blended cement," PHD thesis. College of engineering and applied science, pp. 177, 2000. Report GC 4 Faculty of Engineering Curtin University of Technology Perth, Australia, 2008.

[6 ] Rangan B.V., "Fly Ash Based Geopolymer Concrete," Research Report GC 4 Faculty of Engineering Curtin University of Technology Perth, Australia, 2008.

[7] Palomo. A,S.Alonso, A.Ferna'ndez Jime'nez, I. SoJ. Sakivation of fly ashes.ANMR study of the reaction products,"J.Am. Ceram. Soc. 87 6, pp.11411145,2004.

[8] Rao G.A, "Influence of silica fume replacement of cement on expansion and drying shrinkage," Cement and Concrete Research, Volume 28, No. 10, pp. 1505-1509, 1998.

[9] Hardjito.D and B. V. Rangan, "Development andproperties of low-calcium fly ash-based geopolymer concrete," Research Report GC 1 Faculty of Engineering Curtin University of Technology Perth, Australia, 2005. Xu, H., Van Deventer, J.

[10] M. F. Nuruddin, Sobia Qazi, N. Shafiq, A. Kusbiantoro, "Compressive Strength \& Microstructure of Polymeric Concrete Incorporating Fly Ash \& Silica Fume. Canadian Journal on Civil Engineering Vol.1, No.1, February 2010.

[11] Bahar Demirel, "effect of the waste marble dust as fine sand usings on the mechanical properties of the concrete."International Journal of the Physical Sciences Vol.5 (9), pp. 1372-1380, 18 August, 2010

[12] Hanifi Binici1, Hasan Kaplan and Salih Yilmaz, "Influence of marble and limestone dusts as additives on some mechanical properties of concete.”Scientific Research and Essay Vol. 2 (9), pp.372,379,September 2007.Accepted 6 August, 2007.

[13] Joo-HwaTay, Kuan-Yeow, "Municipal wastewater sludge as cementitious and blended cement materials"

[14] Hyungjin Kim, Nam Woong Lim, "Development of high strength cementitious products using industrial waste sludge" Environ.eng. Res. Vol. 4, No.4, PP.251-258, 1999 Korean Society of Environmental Engineers.

[15 ] Hardjito. D and B.V.Rangan, "Development and properties of low-calcium fly ash-based geopolymer concrete," Research Report GC 1 Faculty of Engineering Curtin University of Technology Perth, Australia, 2005.

[16 ] Guilherme Chagas Cordeiro, Romildo Dias Toledo Filho, and Eduardo de Moraes Rego Fairbairn "Use of Ultra-Fine Sugar Cane Bagasse Ash as Mineral Admixture for Concrete" ACI Materials Journal. Find Articles.com.26 Jul,2011.

[17] G. C. Cordeiro, R.D.Toledo Filho, E. M. R. F airbairn, "Ultrafine sugar cane bagasse ash: high potential pozzolanic material for tropical countries" Cement and Concrete Composites (1994) Volume: 16, Issue: 1, Pages: 39-48 ISSN: 09589465 DOI: 10.1016/0958-9465(94)90029-9

[18] IS 650:1966 "Specification for standard sand for testing of cement" (first revision)

[19] IS 2580:1982 "Specification for jute sacking bags for packing cement" (second revision)

[20] IS 3535:1986"Methods of sampling hydraulic cements" (first revision)

[21] IS 4031 (Part 1to13)" Methods of physical test for hydraulic cement" (first revision)

[22] IS 4032:1985(Part 1 to13)"Methods of chemical analysis of hydraulic cement" (first revision)

[23] IS: 13311-Part I "Velocity Criterion for Concrete Quality Grading"

[24] M.S.Shetty, "Concrete Technology.” M/s S. Chand \& Company Ltd., Pune, May 2005. 